\title{
Growth and distribution: a revised classical model
}

\author{
Crescimento e distribuição: revisãa do modelo clássico
}

LUIZ CARLOS BRESSER-PEREIRA*

RESUMO: Este artigo discute a distribuição e as fases históricas do capitalismo. Parte da premissa de que o progresso técnico e o econômico estão em andamento e, dado isso, sua pergunta se refere à distribuição funcional da renda entre trabalho e capital, tendo por referência a teoria clássica da distribuição e a tendência declinante da taxa de lucro de Marx. Partindo da experiência histórica, o artigo primeiramente inverte o modelo, tratando a taxa de lucro como a variável constante no longo prazo e a taxa de salário como o resíduo; em segundo lugar, distingue três tipos de progresso técnico (poupador de capital, neutro e dispendioso de capital) e o aplica à história do capitalismo, tendo por referência o Reino Unido e a França. Dados esses três tipos de progresso técnico, distingue cinco fases de crescimento capitalista, dentre as quais apenas a segunda condiz com a previsão de Marx. Na fase final, correspondente ao Capitalismo Financeiro-Rentista e neoliberalismo, os salários foram mantidos estagnados, crescendo menos que a produtividade, enquanto a taxa de lucro recuperou-se da queda ocorrida nos anos 1970.

PALAVRAS-CHAVE: Crescimento; distribuição; taxa de lucro; taxa de salário; progresso técnico.

ABSTRACT: This paper discusses distribution and the historical phases of capitalism. It assumes that technical progress and growth are taking place, and, given that, its question is on the functional distribution of income between labor and capital, having as reference classical theory of distribution and Marx's falling tendency of the rate of profit. Based on the historical experience, it, first, inverts the model, making the rate of profit as the constant variable in the long run and the wage rate, as the residuum; second, it distinguishes three types of technical progress (capital-saving, neutral and capital-using) and applies it to the

* Emeritus Professor at Getulio Vargas Foundation, Brazil. E-mail: bresserpereira@gmail.com. Submitted: 16/May/2017; Approved: 11/September/2017.

Paper presented to the conference of the Research Network Macroeconomics and Macroeconomic Policies, "Inequality and the Future of Capitalism", Berlin, November 1, 2014. Revised in September 2017. The model of this paper was originally developed in the book (Bresser-Pereira, 1986). I express gratitude for the comments by Adalmir Marquetti, Adam Przeworski, Daniel Saros, Eckhard Hein, Fabio Anderaos, Fletcher Baragar, Gilberto Tadeu Lima, Luiz Antônio Oliveira Lima, José Luiz Oreiro, Michael Keaney, Takashi Yagi and Yoshiaki Nakano. 
history of capitalism, having the UK and France as reference. Given these three types of technical progress, it distinguishes five phases of capitalist growth, where only the second is consistent with Marx prediction. In the final phase, corresponding to financier-rentier capitalism and neoliberalism, the profit rate recovered from the fall of the 1970s, while wages have been growing below the growth of productivity.

KEYWORDS: Growth; distribution; profit rate; wage rate; technical progress.

JEL Classification: D3; O1; O3; O4; P1.

Capitalist economic growth and the functional distribution of income were discussed by the classical economists, including Marx, but, whereas their explanation of growth as depending on investment and technical progress proved a durable theory, most economists abandoned the classical distribution theory, because it is based in an assumption that proved unrealistic - that the wage rate varies just with the increase of the historical cost of subsistence of labor. This paper aims to restore the classical theory of distribution, but with a change: it inverts the model, assuming that the rate of profit is constant in the long-term, and the wage rate, the residuum. Secondly, by introducing three types of technical progress and showing how it changed historically, it proposes that capitalist development has occurred in five historical phases (Industrial Revolution, Competitive Capitalism, Oligopolistic Capitalism, Fordism, and the Rentier Financier Capitalism), which can be reasonably explained by the model.

Although highly instable, marked by recurrent financial crises, technical progress and growth have been sustained since the capitalist and industrial revolution, whereas income distribution has not been so instable. On the contrary, it has been characterized by a relative stability, which, as I will argue in this paper, derives from the fact that the profit rate must remain satisfactory to business enterprises in the long-term, and that wages and particularly salaries don't need to just cover the social subsistence cost; they may increase above it, along with the increase of the social cost or reproduction of labor and productivity, or even more, provided that the profit rate remains satisfying, and depending on the dominant type of technical progress.

The model that I will present here is not oriented to the causes of economic growth, but, considering that capitalism is dynamic and capital accumulation and growth of the productivity of labor is taking place, it returns to the classical concern with distribution. In the same way of the classical economists, I focus my analysis in the profit rate, not in the interest rate, but, differently of their more illustrious representatives (Smith, Ricardo and Marx), I propose that the productivity of labor, the type of technical progress, the wage rate and the profit rate vary through time thus defining different phases of capitalist development. The classical economists related growth and distribution, but privileging just one type of technical progress, although 
there are two others. Once the industrial and capitalist revolution takes place, ${ }^{1}$ and economic development gets started as capital accumulation and the increase in labor productivity becomes ingrained in the economic process, and it is possible to analyze the main interrelated characteristics of the growth process. Specifically, it is possible to connect historically the types of technological progress with the wage rate and the profit rate, and, so, with functional distribution of income. On the other hand, since economic development is essentially a historical process, it is possible to distinguish phases in this process, and define the stylized facts that characterize it.

I present in this paper a historical model - it is the outcome of the generalization of the regularities and tendencies observed in economic history. It has as reference the UK and France, which presented in a relatively ordered way the several phases of capitalist development. The model that I will present is classical and specifically Marxian, because it deals with the classical concepts of value, labor and capital, because the profit rate plays a key role in economic growth, and because it is based on the model that Marx used to develop his model of the falling tendency of the rate of profit. It is not a Keynesian model, not because I have critiques to it, but because I am not interested here in the tendency to the insufficiency of demand, which is a short-t term problem behind the economic cycles. This is a model where the labor theory of value is assumed. It assumes that wages in the richer countries increased above the historical subsistence level, but they remain, essentially, explained by the cost of reproduction of labor, which increased through time as increasingly sophisticated goods and services required more lengthy and sophisticated education. This is a long-term model, where the effective demand may be assumed as neutral, although this is not always true. It is not a neoclassical model for many reasons that can be summarized in one: because I reject the hypothetic-deductive method that neoclassical economists use - a method that is adequate for methodological sciences, not for substantive science like economics. The fact that the specifically neoclassical models (consistent with the general equilibrium) adopt an inadequate method (good for methodological sciences like mathematics and decision theory) explains why these models are just castles in the air. ${ }^{2}$

This paper is divided in seven short sections. In the first, I discuss why is more realistic to assume that the profit rate is constant in the long-term. In the second, I distinguish the three types of technical progress. In the third, I make the critique of the Okishio Theorem, which asserted to be irrational to choose a technique that will have as consequence the fall of the rate of profit. In the fourth, I make a brief discussion of the theoretical model that I am using, which is based in Marx's falling tendency of the rate of profit. In the fifth section, I discuss briefly the long-term behavior of wages, which tend to increase with productivity, and of productivity of capital, which, in a former worker, I believed to tend to be increasingly capital-

\footnotetext{
${ }^{1}$ By "industrial and capitalist revolution" I mean the long period from the thirteenth to the nineteenth century that gave rise to the modern national states and to capitalism.

${ }^{2}$ See Bresser-Pereira (2007).
} 
saving, but since the 1980s this proved to be wrong, and I try to explain why. ${ }^{3}$ In the sixth session, I present a periodization of capitalist development having the variables of the model, particularly the functional distribution of income, as criterion. And, in the seventh section, I make a short reference to the change the occurred in the ruling classes - the emergence of the professional or technobureaucratic class, which replaced the business entrepreneurs in the management of the correspondence, and or rentier that replaced them in their ownership - and relate them with the phases of capitalist development, which I discussed in the previous section.

\section{PROFIT RATE AS A CONSTANT}

The model here presented assumes a closed economy, generalized competition, no state, one commodity, total and marginal output-capital ratio equal, and just two agents: capitalists, receiving profits, $\mathrm{R}$, and workers, receiving wages, W. Income, $\mathrm{Y}$, is the sum of wages and profits. Capitalists could be differentiated into entrepreneurs making profit and rentiers receiving interests. This distinction is necessary to the model only in the last phase. In the same vein, although I use the state in the argument, it may be ignored in the simpler version of the model. Expenditure is equal to income, and to the sum of consumption, $\mathrm{C}$, and investment, I. The functional distribution of income or plus value rate is $\mathrm{R} / \mathrm{W}=\mathrm{m}$, and the profit rate is $R / K=r$, where $R$ are the total profits, and $K$ is the stock of capital.

Economic growth is defined by the increase of productivity and of income per capita. Since I am not looking for the causes of economic growth, I will simply assume that the economy is growing, i.e., that the productivity rate and income per capita are increasing. Given the assumption that the labor force, $\mathrm{L}$, is increasing at the same rate as population, $\mathrm{N}$, the productivity rate, $\mathrm{Y} / \mathrm{L}=\mathrm{y}$, and the increase of income per capita, $\mathrm{Y} / \mathrm{N}=\mathrm{n}$ are equal. The variation of $\mathrm{y}$ through time is $d y / d t=\dot{y}$, (and the rate of growth of income per capita, y, is $\dot{y} / y=\hat{y}$ ). The wage rate is $\mathrm{W} / \mathrm{L}=$ $\mathrm{w}$; the variation of total wages is $d W / d t=\dot{W}$; the rate of growth of total wages, $\dot{W} / W=\hat{W}$; the variation of the wage rate, $d w / d t=\dot{w}$.

The model does not describe any specific capitalist economy, but has as reference the first developed national states, particularly Britain and France. In the model, as in Kaldor (1956) and in Sraffa (1960), the long-term profit rate is assumed to be constant, except in one specific historical phase - the Marx's Competitive Phase (1815-1870) -, in which it falls from a high level, which prevailed during the Industrial Revolution, to a satisfying level since then, except in the crises, when it falls below this level. The classical model of Smith, Ricardo and Marx assumed the wage rate constant, corresponding to the cost of reproducing of the labor force. This cost could change historically since it is a social cost, but this

\footnotetext{
${ }^{3}$ See Bresser-Pereira (1986). Recently I returned to the theme in Bresser-Pereira (2014).
} 
assumption is inconsistent with the extent that the real wage rate increased in the more developed countries since mid-nineteenth century for the more skilled workers. On the other hand, the classical economists, using different arguments but all involving a fall in productivity, predicted that the profit rate would decline in the long run. This prediction also proved to be false. Since mid-nineteenth century, the profit rate remained basically constant, at a "satisfactory", "satisfying", or "satisficing" 4 level, i.e., the level that business enterprises conventionally (and, so, historically) require when they obtain credit and invest. It varies strongly per economic cycles, and responds to exogenous shocks, but in the long run it remains relatively constant.

Why does it make sense to assume a constant rate of profit? First, because a satisfactory profit rate is a condition for the existence or survival of the capitalist economic system; thus, while a better economic alternative to capitalism is not available, the profit rate will have to remain at a satisfactory level. For some time, it was thought that a command or statist economy could be the alternative, but even whilst this belief was alive it was a distant belief. Given this lack of alternative, capitalist societies must preserve the profit rate. The capitalist system can only survive if a reasonable profit rate is assured to active capitalists or entrepreneurs - a rate reasonably above the interest rate received by rentier capitalists. Second, although capitalist economies and societies are characterized by instability and conflict, they are, in the realm of each national state, a cooperative undertaking. The existence of nation-states presupposes a broad political agreement. Capitalists fight for profits, but they know that a reasonable wage rate is essential for political stability and a sustained aggregate demand. Correspondingly, workers are permanently asking for higher wages, but they know that their wages cannot reduce the profit rate below a given level without endangering the capital accumulation, the growth process, and employment. Third, because the countertendencies to the fall of the rate profit referred by Marx, particularly technical progress, monopoly power, and institutions protecting the rate of profit on the expenses of labor will be always in place when required.

Since classical economists believed that the productivity of labor would decline in the long run, ${ }^{5}$ their bottom line was the wage rate. Yet, in so far as this prediction failed, the alternative bottom line is the profit rate. While the constant wage rate proved a false prediction, and a third alternative - an increasing profit rate in the long run - makes no sense in a competitive economy, wages increasing in real terms in the long run and workers participating from the economic surplus do make sense. When an economy, in its cyclical process of growth, experiments high and sustained

\footnotetext{
${ }^{4}$ Herbert A. Simon (1956[1979]: 20) created the expression "satisficing", arguing that "evidently, organisms adapt well enough to 'satisfice'; they do not, in general, 'optimize' " Here, the expressions "reasonable", "satisfactory" and "satisficing" are synonymous.

${ }^{5}$ Not all classical economists predicted the long run stagnation prospect, but this is clear in Ricardo, Malthus, and Marx.
} 
rates of growth, the wage rate will tend to increase in proportion to the increase of the cost of reproduction of labor (which is higher than the cost of subsistence because it includes the education costs). Theoretically the wage rate may increase up to the moment in which the economy achieves a hypothetical stage of abundance, i.e., up to the point that people have the full freedom to choose between income and leisure, and overwhelmingly decide for the later. In practical or historical terms, the average wage rate will increase till the bottom line represented by a satisfactory profit rate. From this point on, a profit squeeze process will materialize, and the economy will be experiencing fall in the investment rate and crisis, which will only be overcome when the expected profit rate is restored. Since economic agents and politicians need that the economy works, they either take the required policies and institutional reforms to reduce the wage rate, or they search to increase aggregate demand without increasing wages, or they wait that the market system processes the crisis, reduce wages, and reestablishes the profit rate. ${ }^{6}$ The second the Keynesian alternative - is obviously superior, but it will only be viable if there is a clear insufficiency of demand and unemployment, and if the expansive macroeconomic policy will be reverted as soon as it is possible.

When Marx developed the theory of the falling tendency of the rate of profit, he considered the possibility of countertendencies. In the model that I am presenting, the long-term constancy of the rate of profit, assured either by policy, or by technical progress not capital-using, is this countertendency in practice. Even if there were an economic alternative to capitalism, this capitalist would defend fiercely the working of this countertendency. Since there is not for the moment such alternative, capitalist eventually obtain the cooperation of the other social classes in the institutional process of protecting the rate of profit and the process of capital accumulation. Besides the market mechanisms that, to a certain extent, assure the way out of the cyclical crisis, governments are supposed to provide the institutional reforms and policies that will assure this outcome, and, in doing so, it will keep the long run rate of profit at a satisfactory level, consistent with investment and growth.

\section{TYPES OF TECHNICAL PROGRESS}

Technical progress is defined by the increase of the productivity of labor. There is technical progress when productivity is increasing, or, in other words, when workers are being able to increase their average value added. Thus, technical progress involves not only the introduction of new methods of production and new products, but also the transference of labor from activities with lowers to higher valued added per capita. Yet, the process of increase labor productivity will be ac-

\footnotetext{
${ }^{6}$ Thus, in this assumption of a long-term constant profit rate is implicit a theory of the economic cycle, that I sketched in Bresser-Pereira (1986), but that goes off the point of this paper.
} 
companied by changes in the productivity of capital, or the output-capital ratio, Y/K (which Marx called technical composition of capital). ${ }^{7}$ Given the fact that, concomitantly with the increase of labor productivity, the capital productivity may decrease, remain constant, or increase, we have three types of technical progress, which are defined by the behavior of the productivity of capital. If the productivity of capital is decreasing $\left(\mathrm{Y}_{2} / \mathrm{K}_{2}<\mathrm{Y}_{1} / \mathrm{K}_{1}\right.$, where ${ }_{\mathrm{i}}$ indicates time $)$, technical progress will be capital-using - we will have "mechanization". If the output-capital ratio is constant, technical progress will be neutral. And if the productivity of capital is increasing, technical progress will be capital-saving.

In the case of capital-using technical progress - when the productivity of capital is decreasing - output or GDP will be increasing at a smaller rate than the stock of capital:

$$
\frac{\dot{Y}}{Y}<\frac{\dot{K}}{K} \quad \text { ou } \quad \hat{Y}<\hat{K}
$$

In the case of neutral technical progress, where $\mathrm{Y}_{2} / \mathrm{K}_{2}=\mathrm{Y}_{1} / \mathrm{K}_{1}$, income will be increasing at the same rate as capital:

$$
\frac{\dot{Y}}{Y}=\frac{\dot{K}}{K} \quad \text { ou } \quad \hat{Y}=\hat{K}
$$

In the case of capital-saving technical progress - when the productivity of capital is increasing - the total output rate will be higher than capital, and we have increasing returns:

$$
\frac{\dot{Y}}{Y}>\frac{\dot{K}}{K} \quad \text { ou } \quad \hat{Y}>\hat{K}
$$

Capital-using technology, which involves the fall of the output-capital ratio, is typical of the early stages of industrialization and capital formation, when mechanization or the successive substitution of different machines for different forms of labor takes place. On the other side, capital-saving technical progress, which also may be called modernization, derives from the substitution of new machines for old ones of the same type (i.e., which replace the same kind of labor, or performs the same kind of operation that a previous one performed). It is only the type or model of the machine that changes, since it replaces the same type of labor. The new model, however, is cheaper, or more efficient. In this second case, technical progress, besides saving labor, saves capital itself by increasing the output-capital ratio. While in the case of mechanization the only alternative to business enterprise was to invest in increasingly less efficient machines, in this case, it again will not

\footnotetext{
${ }^{7}$ In this paper I used the concept of output-capital ratio, Y/K, which Marx called "technical composition of capital", avoiding the use of the "organic composition of capital" concept which rather complicates than simplifies the argument. In the growth literature, capital-output relation is more often used, but I prefer its inverse, the output-capital ratio, because when one says that this ratio is increasing, this means that capital productivity is increasing.
} 
have other alternative but to invest in increasingly more productive or less expensive machines - machines that can turn out a larger output (with the same quality) per unit of capital. New machines, in this case, are new in relation to other models of machines performing the same operation, while in the previous case are new machines performing new operations and thus replacing new types of labor. New machines appear in the market when they bring some innovation and lower costs, but there is a major difference between new machines performing operations which were previously manual, and new machines replacing old machines. In one case, we have capital-saving technical progress, in the other, capital-using technical progress.

\section{OVERCOMING THE OKISHIO THEOREM}

How can we have, out of rational investment decisions, a situation in which technical progress involves a decreasing output-capital ratio? Or, in other words, which is the microfoundation for the choice of a capital-using technique? Nobuo Okishio $(1961,1977)$ argued that this behavior would be irrational. It is not. Whenever the costs involved in buying and operating a new machine (and the respective production process) is smaller than the use of manpower, it will be rational for the capitalist to invest in this machine. As the business enterprise substitutes capital for labor, the production costs will be reduced, the productivity of labor will increase, and the capitalist who first introduced the new machine will make an extra profit. Yet, the machines available have different productivities, and replace different types of labor. If we suppose that the business enterprises face a decreasing investment opportunities curve, having, in the vertical, the cost reduction achieved, and in the horizontal axes, the respective machines and correspondent production processes available, the business enterprises will, first, invest in a more efficient machine, that replaces one type of labor; second, they will buy the second best machine, which replaces a different type of labor; and so on, up to the point where breakeven is achieved. ${ }^{8}$ Despite the fact that, in this decision process, the productions costs decreases for the business enterprises as different kinds of labor are successively replaced by different kinds of machines with decreasing productivity, each new machine replacing different kinds of labor will reduce the overall outputcapital ratio, or the productivity of capital will decrease.

Take, for instance, the choice of techniques in an economy that has only agricultural production, and that replaced all possible labor for a highly efficient machine, the tractor. Then, another new machine appears, which reduces costs to the companies - a harvesting machine. All farmers must buy it to keep competitive, but

\footnotetext{
${ }^{8}$ This curve is similar to Keynes' marginal efficiency of capital. The difference is that in the marginal efficiency of capital the vertical axis shows directly the expected rate of profit, while in the investment opportunities curve that I am suggesting we have the cost reductions related to the different techniques replacing different types of labor.
} 
as they hold a lower output-capital ratio, after the substitution is completed the total output-capital ratio of the economy will fall, even though their costs were reduced.

There is also the possibility of a new machine that replaces a different type of labor that had not yet been mechanized, and more efficient that the ones previously bought to replace other forms of labor. In this case, in which our cost-machines curve does not hold, mechanization will not cause the fall of the productivity of capital. Yet, this situation will be rather the exception than the rule. The tendency is that innovations (the actual adoption of the invention) take place in sequence in such a way that the first innovations involve high output-capital ratios and the following, increasingly smaller ones. In this case, technical progress will be necessarily capital-using; the output-capital ratio will be declining.

When the output-capital ratio is decreasing, we will see that the profit rate will be decreasing. With this argument, we can understand something that appeared irrational: firms adopting capital-using techniques that, eventually, will reduce instead of increase its profit rate. The Okishio Theorem challenged the possibility of a falling tendency for the rate of profit. Yet, following Anwar Shaik (1978) and my own work at the time, the business enterprise acts rationally and remains competitive when adopts the new technique or machine that is capital-using but efficient. ${ }^{9}$ This is a defensive strategy to keep the firm competitive, given the fact that the other firms will also adopt the capital-using but cost reducing technique. Once all business enterprises replace manpower for a relatively (to the previous ones) less efficient machine (but more efficient than direct labor), the resulting output-capital ratio for the whole industry will fall and the average rate of profit will be smaller. This is a non-predicted consequence, out of the control of each individual firm; it is a perverse but rational effect of mechanization or the adoption of capital-using technical progress.

In the case of neutral technical progress, there is not a specific form of substitution of capital for labor, or the need of reasoning in terms of microfoundations. This sort of technical progress just exists in so far as the two previous processes mechanization and modernization - compensate one another. At every moment, we will have new types of labor being replaced by new types of machines, and old machines being replaced by new models of the same machines ("same" just in so far it replaces the same type of labor). In the first case, technical progress will be capital-using, in the second, capital-saving. If the negative effect of the first is compensated by the positive of the second, technical progress will be neutral. Most growth models concerned with equilibrium (or lack of it) and with the determinants of the rate of growth, as the case of the Harrod-Domar and the Solow models, assume neutral technical progress. In the relatively short or medium-term periods in which such models are usually used, such assumption is reasonable and simplifies

\footnotetext{
${ }^{9}$ Anwar Shaikh (1978) made a critique of the Okishio Theorem similar to this one that I am making here. We both were working independently, but he published his finding some years before (1986).
} 
the model. In the present model, however, principally concerned with distribution in the long-term, across several historical stages or phases of economic development, to abandon such assumption is essential.

\section{THE ABSTRACT RELATIONSHIPS}

Given these three forms of technical progress, or the variation of the outputcapital ratio, we have different behaviors of the other central economic variables: the profit rate, the wage rate, and the functional distribution of income. These variables are related among themselves following a simple identity:

\section{$\mathrm{R} / \mathrm{K}=\mathrm{R} / \mathrm{Y} / \mathrm{K} / \mathrm{Y}$}

where $\mathrm{R} / \mathrm{K}$ is the profit rate, $\mathrm{R} / \mathrm{Y}$ is a measure of distribution (that can also be expressed as $\mathrm{R} / \mathrm{W}$, since $\mathrm{R} / \mathrm{Y}=1 /(1+\mathrm{W} / \mathrm{R})$, and $\mathrm{K} / \mathrm{Y}$, the capital-output ratio.

Let us suppose, first, that the functional distribution of income between profits and wages is constant: $\mathrm{R} / \mathrm{Y} \rightarrow$. In this case, and just having in mind that an increasing capital-output ratio means a decreasing output-capital ratio, it is easy to see, from identity (1), that, if technical progress is capital-using (declining outputcapital ratio, $\mathrm{Y} / \mathrm{K} \downarrow)$, the profit rate will be declining, $\mathrm{R} / \mathrm{K} \downarrow$; if technical progress is neutral (constant output-capital ratio, $\mathrm{Y} / \mathrm{K} \rightarrow$ ), the profit rate will be constant, $\mathrm{R} /$ $\mathrm{K} \rightarrow$; and if technical progress is capital-saving (increasing output-capital ratio, $\mathrm{Y} /$ $\mathrm{K} \uparrow)$, the profit rate will be increasing, $\mathrm{R} / \mathrm{K} \uparrow$.

Thus, we cannot speak of a general tendency of the rate of profit to fall, increase, or remain constant just out of (1). Depending on the type of prevailing technical progress, and given a constant functional distribution of income, the rate of profit will correspondingly fall, remain constant, or increase. If, instead, we assume that the constant variable in the long run is the profit rate, as I already argued, and that economic growth is taking place, which will be functional distribution of income and the wage rate for each type of technical progress?

To answer this question, considering that the growth rate of $\mathrm{R}$ and the growth rate of $\mathrm{K}$ are equal, I start by taking the time derivative of equation (1), setting it to zero, and substituting $\mathrm{R}+\mathrm{W}$ for $\mathrm{Y}$.

Computing the derivatives and doing some algebraic manipulations we have the following equation:

$$
\frac{d}{d t}(R / K)=\frac{d}{d t}\left[\frac{R /(R+W)}{K / Y}\right]=0
$$

The left-hand side of the equation (2) has the same sign as the rate of change of the functional distribution of income R/W and the right-hand side has the opposite sign to the rate of change of $\mathrm{Y} / \mathrm{K}$, since: 


$$
\frac{\dot{R}}{R}-\frac{\dot{W}}{W}=-\left(\frac{\dot{Y}}{Y}-\frac{\dot{K}}{K}\right) \frac{Y}{W}
$$

Therefore, equation (2) tells us that if technical progress is capital-using, or Y/ $\mathrm{K} \downarrow$, the functional distribution of income will concentrate, so that $\mathrm{R} / \mathrm{W} \uparrow$. If technical progress is neutral, the functional distribution of income will remain unchanged, and if technical progress is capital-saving, or $\mathrm{Y} / \mathrm{K} \uparrow$, it must be that $\mathrm{R} / \mathrm{W} \downarrow$

$$
\begin{aligned}
& \frac{d}{d t}(Y / K)=\frac{Y}{K}\left(\frac{\dot{Y}}{Y}-\frac{\dot{K}}{K}\right) \\
& \frac{d}{d t}(R / W)=\frac{R}{W}\left(\frac{\dot{R}}{R}-\frac{\dot{W}}{W}\right)
\end{aligned}
$$

Now, to understand what happens to the wage rate, let us assume that the population is constant. In a more complete version of the model, population is increasing at a constant rate. Yet, to simplify the equations and show more clearly the relations between the variables, we assume that population is constant, and then the wage rate, W/L, will depend only on the change of $\mathrm{W}$. We now re-write equation (2) to analyze how $\mathrm{W}$ varies:

$$
\frac{\dot{W}}{W}=\frac{\dot{R}}{R}+\left(\frac{\dot{Y}}{Y}-\frac{\dot{K}}{K}\right) \frac{Y}{W} \geq \leq 0
$$

Because the profit rate is assumed to be constant, we can substitute the rate of growth of capital for the rate of growth of profits in the above equation, which after some algebraic manipulations yields:

$$
\frac{W}{Y} \frac{\dot{W}}{W}=\frac{\dot{Y}}{Y}-\frac{R}{Y} \frac{\dot{K}}{K} \geq \leq 0
$$

From equation (3) we deduce that, if technical progress is neutral or capitalsaving, total wages increase because $0<\mathrm{R} / \mathrm{Y}<1$ for positive wages and profits, which makes the right-hand side of equation (3) positive when the rate of growth of output is equal to or higher than the rate of growth of capital. Given the assumption of a constant population, when technical progress is neutral or capital-saving, the wage rate will also increase.

On the other hand, when technical progress is capital-using, equation (3) gives us an ambiguous result. If capital grows at a higher rate than output, the right-hand side of equation (3) will be either positive or negative, depending on the magnitude of $\mathrm{R} / \mathrm{Y}$. Table 1 summarizes these results. In the case of capital-using technical progress or mechanization, which involves a concentrated functional distribution, the wage rate may be decreasing, depending on the rate of growth of income per capita, 
which influences R/Y. In the summary analysis of the historical stages of capitalist growth, the fall in the output-capital ratio only takes place in the two first stages. In the first stage, the Industrial Revolution, in which mechanization is assumed, this ambiguity is present. To keep the rate of profit constant, the wage rate probably fell. In the second phase, is the profit rate that falls, because the wage rate reached the subsistence level and cannot fall more. In this phase the ambiguity disappears despite mechanization, because I dropped the assumption that the rate of profit was constant and assumed that it was falling, because it was exceptionally high during the Industrial Revolution. This allows the wage rate to remain approximately constant and inequality to increase, as probably happened in this period.

Table 1: Consequences of technical progress over the wage rate and distribution, given a constant profit rate

\begin{tabular}{|l|c|c|c|}
\hline & $\begin{array}{l}\text { If technical } \\
\text { progress is }\end{array}$ & $\begin{array}{c}\text {...the wage rate } \\
\text { will be }\end{array}$ & $\begin{array}{c}\text { \& distribution } \\
\text { will be: }\end{array}$ \\
\hline Capital-using & $\mathrm{Y} / \mathrm{K} \downarrow$ & $\mathrm{W} / \mathrm{L} ?$ & $\mathrm{R} / \mathrm{W} \uparrow$ \\
\hline Neutral & $\mathrm{Y} / \mathrm{K} \rightarrow$ & $\mathrm{W} / \mathrm{L} \uparrow$ & $\mathrm{R} / \mathrm{W} \rightarrow$ \\
\hline Capital-saving & $\mathrm{Y} / \mathrm{K} \uparrow$ & $\mathrm{W} / \mathrm{L} \uparrow$ & $\mathrm{R} / \mathrm{W} \downarrow$ \\
\hline
\end{tabular}

\section{WAGES AND PROFITS}

In this model, the two long-term key variables are the wage rate and the rate of profit. The classical economists were right when they made wages dependent on the cost of the reproduction of labor, and the definition of this cost in historical or social terms makes sense. But there is no need to equalize the cost of the reproduction of labor to the subsistence level. The cost of reproduction and, so, the value of labor increased throughout capitalist development as the economic system become more and more complex, more and more sophisticated. This fact does mean that the profit ceases to be labor non-payed. Profit is only possible if the worker can produce more than his cost of reproduction, but from this does not follow that this cost needs to be equal to the subsistence level.

Once economic growth or the increase of income per person assumes a systematic character, the cost or reproduction of labor tends to get separated from the subsistence level and increase around the increase of productivity. In fact, beginning in the second half of nineteenth century, wages became separated from the cost of the reproduction of labor, which then turned into a gauge, rather than the only determining factor for the long-term wage rate of the capitalist system. In the shortterm, the wage rate continues to depend on the accumulation rate. The factor that basically limits an explosive growth of the wage rate at the peak of an economic cycle is still the industrial reserve army. A recessive economic policy, which reduces aggregate demand, guarantees that full employment will not be reached. But the 
long-term wage rate grows in keeping with the increase in the productivity of labor that is translated into an increase of the rate of surplus. The bargaining power of the workers guarantees this increase, if, in the long-term, it does not affect the profit rate that is considered satisfying by the capitalists.

Figure 1: Real wages of craftsmen in Southern England (1260-1954)

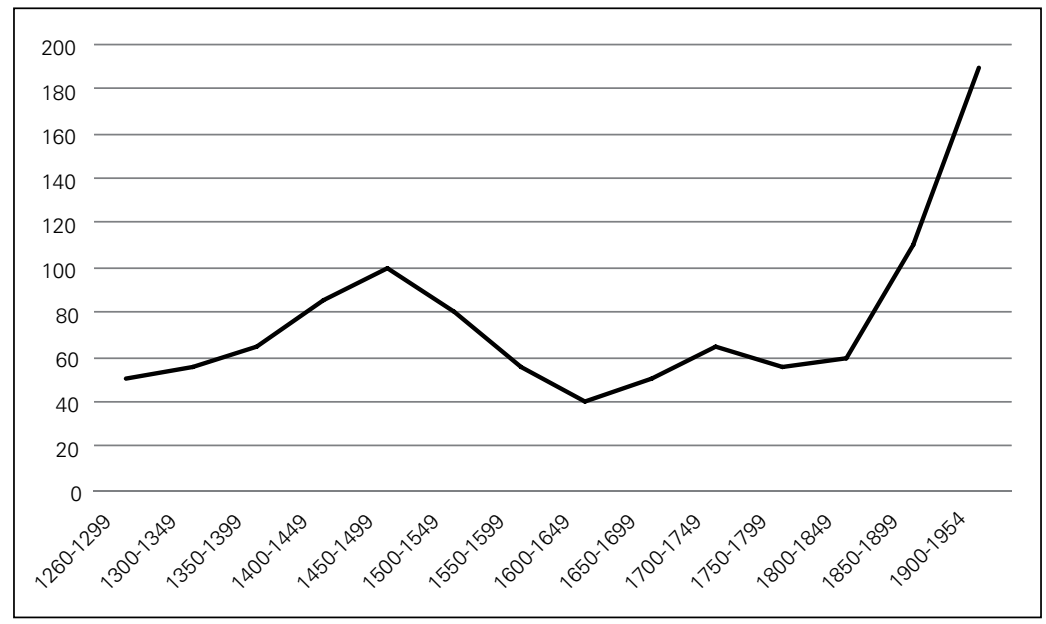

Source: Phelps-Brown and Hopkins (1981, Appendix B).

The rate of productivity labor increases systematically from around 1800 in England, the wage rate was kept around the subsistence level up to mid $19^{\text {th }}$ century, increasing thereafter with the increase of productivity, below, equal, or above the growth of the productivity, depending essentially on technical progress being, respectively, capital-using, neutral, or capital-saving. I was not able to find studies on growth of productivity and of the real wage rate before the $19^{\text {th }}$ century, but there are data on real wages. Figure 1 shows the data of Phelps-Brown and Hopkins (1981) on the growth of real wages of building craftsmen in Southern England from 1260 to 1954 . There is an inexplicable increase from 1260 to 1450, followed by a fall from 1450 to 1650. Robert C. Allen (2001) and Gregory Clark (2007) find the same anomaly, but also does not explain it. Not considering it, we may say that the wage rate remained at the subsistence level up to 1850, growing fast after that. Given that the profit rate was kept constant, this growth of the wage rate was necessarily a growth the around the increase of the productivity of labor. Limited to a shorter period (1750-1913), the research by Crafts and Mills (1994: 179-182) arrives to similar results. Wages that were stagnant up to 1820 , from this year and particularly from 1850 begin to grow steadily. Taking 1900 equal 100, wages are around 35 up to 1820, go up to around 45 up to 1850, and increase to 104 in 1913.

As to the constancy of profit rate, Figure 2, presents the rate of profit of the United Kingdom from 1770 to 2010 according to Thomas Piketty. As we can see, it is constant during the whole period. There is an increase beginning in the late 1930s, but from the mid 1950s it falls and returns to its long-term constant level. 
Figure 2: Rate of profit in the United Kingdom (1770-2010)

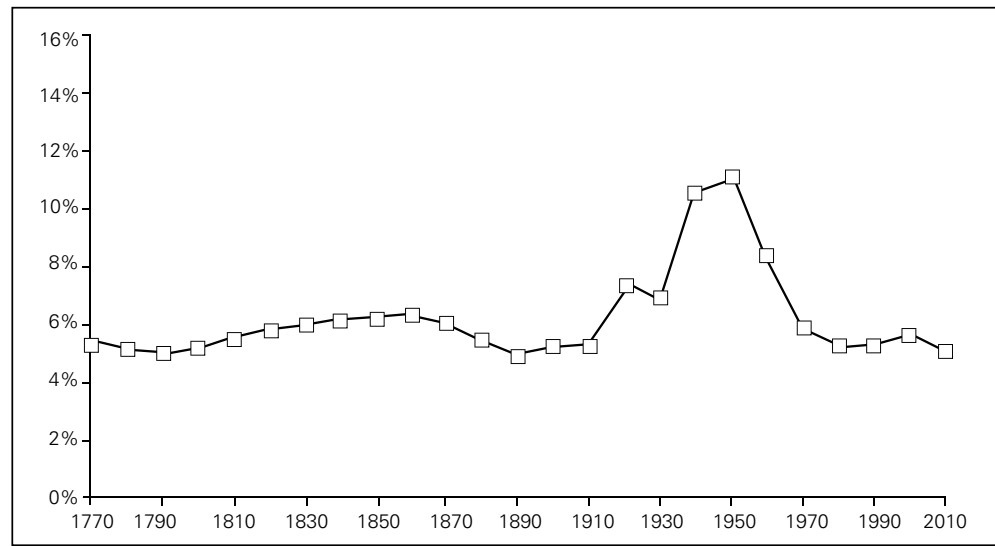

Source: Thomas Piketty (2013, p. 318).

Figure 3: Rate of profit in the US (1870-1990)

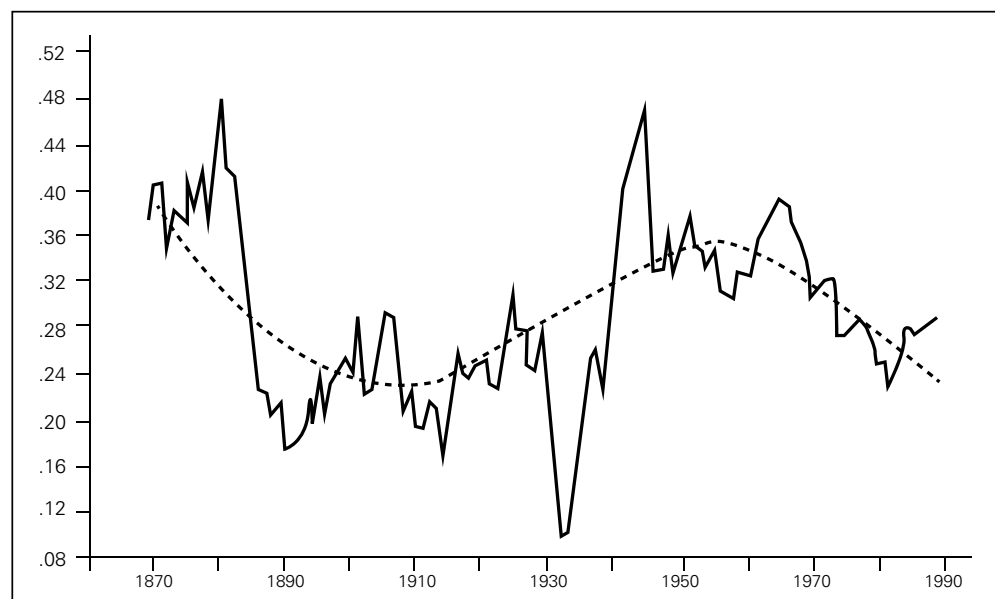

Source: Duménil and Levy (1996, p. 214).

We come to the same conclusion examining Figure 3, the profit rate in the United States, after the Civil War, has undergone two major falls, around 1880 and 1930, soon recovered. Duménil e Levy (2003, p. 20) show that long-term changes in the profit rate "reflect changes in the economic cycle", and follow approximately the changes of the productivity of capital and of the wage rate, but "the average tendency for the whole period is practically horizontal". What means that, except in that two years, the profit rate before taxes between 1869 and 2000 remained in a satisfying level for the companies to continue to invest: around $17 \%$ of the stock of capital. 
There are two interconnected historical reasons and a rational one why the rate of profit is constant at a satisfying level in the long-term. Historically it didn't fall, because the countertendencies to the falling tendency of the rate of profit did their job, and they did because, for the time being, an alternative mode of production to capitalism was not found. The 1979 decision of the ruling Chinese technobureaucracy to change their economic regime from statist to capitalist, from a planned to a market economy, and, in 1991, the collapse of the Soviet Union, as well as the economic superiority of the capitalist regimes in West Germany and South Korea in comparison to East Germany and North Korea are definite demonstrations of this fact. As I wrote elsewhere, although the revolutions in Russia and in China were socialist, socialism soon proved unviable and was immediately replaced by a statist or fully technobureaucratic mode of production. ${ }^{10}$

\section{HISTORICAL PHASES}

The theoretical tools that we have gathered up to now allow us to make a brief analysis of the phases of capitalist development beginning with the Industrial Revolution. My key reference variable will be technical progress or the productivity of capital, the profit rate and the wage rate. My basic reference will be England, which experienced originally all phases of capitalist development. I know that historical growth processes are extremely complex and vary from country to country, but, as we simplify economic relations, we can do the same with economic history, and think in terms of historical phases or stages. To generalize, I distinguish in Table 2 five phases of capitalist development, each one followed by a transition crisis. In each phase, we have four key variables - the productivity of capital $\mathrm{Y} / \mathrm{K}$; the rate of profit, $\mathrm{R} / \mathrm{K}$; the wage rate; $\mathrm{W} / \mathrm{L}$, and the functional distribution between profits and wages, $\mathrm{R} / \mathrm{K}$. To simplify, the increase of the productivity of labor is supposed to be constant. These four ratios have necessary relations among them that the previous abstract analysis resumed. Giving the profit rate constant (except in Competitive Capitalism), wages will increase less, equal, or more than the increase of the productivity of labor depending the technical progress is capital-using, neutral, or capital-saving. When the wage rate falls (in the Industrial Revolution) or increases less than the productivity of labor, inequality increases. In just one phases, Fordism or the Golden Years of Capitalism, inequality has fallen.

${ }^{10}$ Bresser-Pereira (1972, 1977, 1981, 2009). 
Table 2: Phases of capitalist development and three key variables

\begin{tabular}{|l|c|c|c|c|c|}
\hline \multicolumn{1}{|c|}{ Phases } & Years & $\begin{array}{c}\text { Technical } \\
\text { progress }\end{array}$ & Profit rate & Wage rate & Inequality \\
\hline $\begin{array}{c}\text { Industrial Revolution } \\
\text { Crisis (1800-1815) }\end{array}$ & $1750-1800$ & - & $\begin{array}{c}\text { Constant } \\
\text { (high) }\end{array}$ & Falling & Increasing \\
\hline $\begin{array}{l}\text { Competitive or } \\
\text { Marx's Capitalism } \\
\text { Crisis (1873-1890) }\end{array}$ & $1815-1873$ & Capital-using & Falling & Constant & Constant \\
\hline $\begin{array}{l}\text { Oligopolistic Capitalism } \\
\text { Crisis (1929-1945) }\end{array}$ & $1890-1929$ & Neutral & Constant & $\begin{array}{c}\text { Increasing with } \\
\text { productivity }\end{array}$ & Constant \\
\hline $\begin{array}{l}\text { Fordism } \\
\text { Crisis (1973-1978) }\end{array}$ & $1946-1973$ & Capital-saving & Constant & $\begin{array}{c}\text { Increasing more } \\
\text { than productivity }\end{array}$ & Falling \\
\hline $\begin{array}{l}\text { Rentier-financier } \\
\text { capitalism } \\
\text { Crisis (2008-...) }\end{array}$ & $1979-2008$ & Capital-using & Constant & $\begin{array}{c}\text { Less than } \\
\text { productivity }\end{array}$ & Increasing \\
\hline
\end{tabular}

Industrial Revolution (1750-1800). The Industrial Revolution is the moment when the capitalist revolution, which began with the Commercial Revolution, and was followed by the formation of the nation-state, came to a close in England. I In Rostow's terms (1960), it is when the takeoff takes place. It happened in the original countries after the long process of the rise of a mercantile bourgeoisie and of primitive accumulation, in the framework of mercantilist capitalism (the first historical form of developmental state and of developmental capitalism), ${ }^{11}$ which created the conditions for the subsequent generalization of wage labor and the competitive appropriation of surplus through profits (Marx, 1867, I, p. 24). The Industrial Revolution was a concentrated process of industrialization involving positive externalities or spillovers, and, consequently, high profit rates. It was characterized by a high and relatively constant profit rate, ${ }^{12}$ while technical progress was dominantly capital-using, or, in other words, the output-capital ratio or the productivity of capital was falling. This is consistent with a declining wage rate, because I am assuming that workers, immediately before the Industrial Revolution, had a standard of living above mere subsistence: the first moment of industrialization represented for them proletarization or pauperization.

Competitive Capitalism or Marx's Phase (1815-1873). In this period where economic liberalism or competitive capitalism is dominant. The transition from pre-capitalism was completed. The economy is characterized by a large number of small and medium sized family enterprises. It is essentially competitive, since the

\footnotetext{
${ }^{11}$ Bresser-Pereira (2017).

12 "Relatively" constant because, here, the "constancy" is associated to the key fact that the profit rate in the industrial revolution was high, above the satisfying level.
} 
gigantic business enterprises are not yet present. The economic system corresponds to the one predicted and described by Marx, because it is the period that technological progress is capital-using and when the profit rate falls. Technical progress remains capital-using or the productivity of capital continues to fall because mechanization (the substitution of capital for labor) continues intense, overcoming the modernization process. Thus, we have decreasing returns. Yet, the wage rate does not fall but remains constant since it was at the subsistence level. The profit rate may decrease without harming investment because we assume that it was very high during previous phase. This decrease leaves ambiguous the functional distribution of income, which probably continues to concentrate, but much less than in the previous phase, and may even have remained constant, depending on the rate of growth of the income per capita. This phase ends with an economic depression between 1873 and 1890 .

Oligopolistic Phase (1890-1929). By the end the nineteenth century, around 1890 , in the framework of the Second Industrial Revolution, capitalism gets fully consolidated, Mass production techniques are introduced, the explosion motor replaces the steam motor, and electrical power is dominated and diffused. Therefore, the economic system turns oligopolistic, dominated by large business enterprises start. Workers, on their turn, get organized in large unions. Both changes were interdependent: the higher level of workers' organization was only possible in view of the relative oligopolization of markets. From this, follows a major consequence: workers became capable of retaining the productivity gains. Economic theory based on competition assumed that productivity increases would just lead to lower costs which would benefit all, including foreign consumers. The new workers' organization capacity turned possible that, in the late 1940s, the Prebisch's and Singer's these on the uneven distribution of the productivity gains between developed and developing countries was formulated: while industrial countries, where labor was organized, could conserve productivity gains, disorganized workers producing primary products in developing countries were not, from that deriving the deterioration of the terms of exchange.

For our model, only the first aspect of the problem is important. With the Second Industrial Revolution, these characteristics are just enhanced. Markets are increasingly oligopolistic, but business enterprises remain competitive enough to keep centrally concerned with the incorporation of technical progress. In so far as mechanization and capital-savings technology compensate one another, the outputcapital ratio is basically constant (as growth models usually assume), or, in other words, technical progress is neutral. From this moment on, workers would be able to augment their wages per the productivity rate without threatening the profit rate. Capitalism achieves its classical moment. This phase ends with the 1929 financial crash in the United States and the Great Depression.

Fordism (1946-1973). Franklin Delano Roosevelt's bold reforms rejecting economic liberalism and bringing back capitalism to its developmental origins an- 
nounce the Fordism or the Golden Years of Capitalism. ${ }^{13}$ In this phase, we have a strong increase in labor productivity, ${ }^{14}$ the productivity of capital remains constant, the rate of profit remains satisfying, and the wages increase with the productivity of labor. In consequence, a moderate reduction of inequality materializes. Fordism is the moment where the United States achieves full economic and political hegemony, and the moment when the Western European countries catch up while building the Welfare State. During Fordism, the constancy of the profit rate was consistent with wages rising faster than the productivity of labor. In fact, in the Fordist period the advanced economies experienced high rates of growth and financial stability, while inequality clearly diminished, not only due to the increase of the productivity of capital and to the augmented power of organized labor, but also due to indirect wages represented by the large social services of the Welfare State.

Yet, since 1965, as unemployment was zeroed and the relative power of the unions increased, profits were squeezed (Boddy and Crotty, 1975; Goldenstein, 1999). ${ }^{15}$ On the other hand, from the 1973 first oil shock and the rise of inflation, rich countries felt constrained to adjust, and the growth rates fell. The Golden Years of Capitalism were over, and capitalism headed for a major and reactionary change.

In the crisis and transition years from Fordism to the Financier-Rentier or Neoliberal Years of Capitalism(1966-78) the productivity of capital fell, wages continued to increase, and the profit rate fell sharply. ${ }^{16}$ According to Duménil and Lévy (1993, p. 299), the output-capital ratio starts falling in 1966; Thomas Piketty (2013, p. 309) concurs: the ratio output-capital or the productivity of private capital of rich countries falls sharply in the 1970s: "whereas private capital represents between 2 and 3,5 years of national income in the rich countries in 1970, it represents between 5.1 and 5.2 in 2010". In consequence, the profit rate falls (Duménil et Lévy 1996, p. 214). It falls also because wages increase more than productivity, due to the increased power of the unions in the end of the 1960s.

Rentier-Financier Capitalism (1979-2008). The Neoliberal Years of Capitalism

\footnotetext{
${ }^{13}$ Capitalism was born with mercantilism - a form of economic and political organization of capitalism where the state had a major role in coordinating the economic system, by regulating the market and complementing it. The first industrial revolutions (UK, France and Belgium) took place in the historical context of mercantilism.

${ }^{14}$ The productivity of labor and, so, economic growth increased in this phase more than in the other phases, and for that reason the post-war period came to be called the Golden Years of Capitalism (Glyn, 1988; Marglin, 1990).

${ }^{15}$ According to Nordhaus et al. (1974), the participation of the profits of the corporations in the total income in the United States fell from $22 \%$ in 1950 to $11 \%$ in 1974. Victor Perlo (1976) made of series of criticisms to this data, but the fall of the profit rate in the 1970s was confirmed later by other data and is undeniable.

${ }^{16}$ According to Duménil and Lévy (1993, p. 299), the output-capital ratio starts increasing in 1966, whereas for Thomas Piketty (2013, p. 309) it increases permanently since 1950; but in a previous page in his book Piketty (2013, p. 270) remarks that in the 1970s there was a sharp fall in the productivity of private capital of rich countries: "whereas private capital represents between 2 and 3,5 years of national income in the rich countries in 1970, it represents between 5.1 and 5.2 in 2010".
} 
were the years of radical economic liberalism. The objective of the neoliberal reforms from the 1980s (privatization, deregulation, commercial and financial opening that, together with the direct investments of the multinational corporations, caused globalization), as well as of the efforts aiming to make less costly to business enterprises labor contracts were a strategy to reduce direct and indirect wages. They were the response of the rentier and financier elites to the 1970s' falling rate of profit. From the mid-1990s the rate of profit has recovered to the satisfying or normal level (Wolff, 2001; Brenner, 2002; Duménil and Lévy, 2002), but this didn't appease the rentiers, the financiers and the top executives of the great corporations - the richest 1 per cent - who formed now the new and narrow dominant liberal class coalition. ${ }^{17}$ The fundamental objective was to retrieve a satisfactory profit rate was achieved, despite the productivity of labor was also falling (Strassmann 2004), by reducing direct and indirect wages - reducing direct wages by making more flexible or more precarious the labor contracts, so reducing the direct costs of labor; and reducing indirect wages by searching to reduce the large social services that the state has undertaken since the end of World War II, and that proved to be efficient in rising the standards of living, while made citizens more secure. ${ }^{18}$

In the Rentier-Financier Capitalism wages were kept stagnant or growing substantially less than productivity, while technical progress, which had been neutral in Fordism, turned again capital-using. This fact was a surprising consequence of the Information and Communication Technology Revolution. In a first moment, as the price of computers fell dramatically, one could suppose that technical progress would be capital-saving - that the productivity of capital would increase. ${ }^{19}$ But the increase or decrease of the productivity of capital depends on the pace of substitution of capital for labor compared with the pace of substitution of new machines for old machines, or, in other words, depends on the pace of mechanization compared with modernization. And it seems clear that information technology the productivity of labor is outpacing the productivity of capital.

Three other factors explain the war on labor rentier-financier has been waging, which are independent from the type or technical progress. I just mention them here: the fact that rich countries begin to confront with the competition of developing countries in the exports of manufactures since the 1970s, the brutal increase of the remuneration of the top executives of the big corporations that requires a higher pre-bonus profit rate, and the political hegemony that financier-rentier capitalism achieved after the fall of the Berlin Wall and the collapse of Soviet Union.

\footnotetext{
${ }^{17}$ The recovery of the profit rate during the neoliberal years is not unanimous in the political economy literature. Alan Freeman (2012), considering financialization, changes the value of the accumulated capital and arrives to a different conclusion.

${ }^{18}$ On the efficiency of the large social service, take the case of the cost of health in the United States, where it is essentially private, and in Western and North Europe, where it is public. The cost of health care in Europe is 11 percent of GDP, against 17 percent in the United States.

${ }^{19}$ This was the assumption in Bresser-Pereira (1986).
} 


\section{TECHNOBUREAUCRATIC AND FINANCIER-RENTIER CAPITALISM}

In the end of the nineteenth century, the Second Industrial Revolution, the rise of the big corporations and the relative separation of ownership from the control of these corporations changed capitalism's ruling classes. Capitalism turns technobureaucratic or knowledge capitalism, in so far that the technobureaucracy or the professional class was beginning to replace business entrepreneurs in the management of such corporations and, so, sharing power and privilege with the bourgeoisie. As John K. Galbraith (1967) remarked, technical, organizational and communicative knowledge had replaced capital in the role of the "strategic factor of production". ${ }^{20}$ This new class is then a big new middle class benefiting from good salaries. After World War II a second major change happens in capitalism, as rentiers began to replace business entrepreneurs in the ownership of corporations. At the same time, capital turned plentiful, because, since 1945, the accumulated capital ceased to be destroyed by cyclical depressions and major wars. To deal with such glut of capitals in search of limited opportunities to investment, to manage the immense wealth of rentiers, a special kind of technobureaucrats - the financiers - emerge, leading capitalism to be called "financialized" (Chesnais, 1994; Coutinho and Belluzzo, 1998) or finance-led (Guttmann, 2008, 2016) or, as I prefer to say, capitalism turning, besides a technobureaucratic, "rentier-financier capitalism", so as to underline the key role that now rentier capitalists play - an idle class as was the aristocracy before the capitalist revolution.

Now, in Rentier-Financier Capitalism, the top stratum is formed by the capitalist rentiers, the top executives of the multinational corporations and the financiers. In the rentier class the traditional middle, which combines their own salaries and professional incomes with capitalist rents (interests, dividends and real-state rents) is included. These three classes get associated politically, control the media, finance the politicians, thus forming the neoliberal or rentier-financier class coalition. Whereas this class coalition is narrow, the precedent class coalition of entrepreneurcapitalists, the middle class and the popular classes of the Fordist Phase was a broad class coalition. Whereas in Fordism almost all players shared the yields of development, during Fordism, in the Rentier-Financier Capitalism, only the rentier capitalists, the financiers who manage their wealth, and the top executives of the corporations are the winners; all others, "the rest", are losers. In the new time, three major financial innovations (the creation of the Eurodollar currency in the 1960s because the London-based banks accepted to offer dollar-denominated time deposits and loans, the creation of a wholesale money markets, and the transformation of the great banks in the major actors in this market) resulted in a brutal increase in the gains of the financiers and rentiers. Thus, one additional explanation for the relative

\footnotetext{
${ }^{20}$ There is a big literature on the professional or technobureaucratic class, before and after Galbraith's acknowledge the existence of a "technostructure". I participated actively of this theme is the 1970s, but I cannot review this literature here.
} 
stagnation of wages in rich countries since the mid 1960s (additionally to the reduction of the productivity of capital brought by the Information and Communication Technology Revolution) were the high salaries and bonus paid to the top technobureaucratic class.

This is a theoretical paper that used Marx's concepts on the falling tendency of the rate of profit to understand the phases of capitalism development. There is large empirical literature on the profit rate following the Marxist approach. The contributions of Weiskopf (1979), Shaikh (1992), Duménil and Levy (1993, 1996, 2002), Wolf (2001), Brenner (2002), Roberts (2009), Bakir and Campbell (2010) deal mostly with the twentieth century and are consistent with a constant and satisfying rate of profit - a key assumption in this study. The profit rate only falls throughout the phase in the Competitive or Marx's phase. The productivity of capital, on its hand, falls as expected in this phase, turns neutral in the Oligopolistic and in the Fordist phase, and, surprisingly, is back to a capital-using technical progress in the Neoliberal Years. The wage rate, which increases with the increase of productivity since the Competitive phase, also surprisingly (but coherently) grows below the increase of the labor productivity if does not remain stagnant.

In his study of the inequalities in capitalism, Thomas Piketty (2013, pp. 386, 498) underlies that the inequalities originated from the revenues of capital are bigger than the ones originating from labor: "whereas the revenues of labor of the top $10 \%$ receiving more revenues are around $25 \%$ to $30 \%$ of total revenues, the revenues of capital of the top $10 \%$ is always superior to $50 \%$ ". Yet, principally to explain the explosion of the inequality that took place in the US since the 1970s, he believes that the inequalities of labor - specifically of the very high salaries explains a substantial part of it. "The increase of the wage and salary inequalities in the US refers, more than anything else, to the very high salaries: the $1 \%$ of the highest remunerations, and still more, of the $0,1 \%$ highest... Concretely, remunerations around 100000 dollars-200 000 dollars have increased only faster than the average, while the ones above 500000 dollars (and in particular the remunerations of several millions of dollars) have literally exploded".

In all these phases, the productivity of labor increased, or, in other words, technical economic growth or technical progress was happening. Major crises marked the end of each phase, followed by recovery of the profit rata and of the growth rates, but the recovery from the 1970s crisis was subdued, and the recovery from the 2008 global financial crisis, incomplete. That is the reason why the secular stagnation theme was back in the works of Summers (2014), Streeck (2014), Gordon (2016), Aglietta (2016). The last author, however, discard the stagnation hypothesis, and predicts a new wave of innovations based on the control of global warming.

As I remarked in the beginning of the paper, these model that I borrowed from Marx do not deal with the factors that cause a higher or a smaller rate of growth, but with the behavior of the profit and the wage rate, and, so, with the functional distribution of income between profits and wages, with just a reference to salaries and bonuses of the top technobureaucracy. Yet, it must be said that the three forms 
of technical progress imply rates of growth, because technical progress is defined as the increase of labor productivity. In this paper, the output-capital ratio or the productivity of capital plays a role not only in distribution but also in growth. Given the other variables constant, growth will be higher if technical progress is capital-saving than if it is neutral, and still higher if it is compared with a moment in which capital-using techniques predominate. The problem is that policymakers have little influence in the productivity of capital. This is one among several other reasons why catching up has proved so difficult for developing countries, where the productivity of capital - which is often falling because mechanization (capitalusing technical progress) - prevails over modernization (capital-saving technical progress). Yet, the model does not say which will be this rate, because the increase in the labor productivity does not depend only on the type of technical progress, it also depends on the intensity of technical progress: periods of intense technical progress will tend obviously to show higher rates of growth than periods where innovation gets protracted. In macroeconomic terms, this intensity, on its hand, will depend, on the rate of capital accumulation; and in microeconomic terms, on many variables, as education, entrepreneurial capacity, labor and entrepreneurial motivation, rational allocation of resources, institutions adequate to growth, and particularly a national development strategy.

\section{CONCLUSION}

The revised classical model of growth that I just presented is a historical model. It is classical because it is focused in the rate of profit, which is key determinant of capital accumulation and growth. It is revised, because I inverted the classical distribution, and took the profit rate, not the wage rate, as the constant, varying with the short and the long economic cycles, but, out of crises, keeping at a satisfying level. This is an abstract model on growth and distribution, where the stylized facts on how economic growth and the functional distribution of income took place in the different phases of capitalist development. The model aims at being simple and general without losing a historical perspective. Thus, it assumes a closed economy, competition, and the existence of only two economic agents: capitalists and workers. The state is present in the model not as an economic agent collecting taxes and providing economic transferences, but only defining the institutions required for markets to operate and the profit rate to be assured at a satisfying level. In the model, technological progress is defined by the increase of labor productivity (which corresponds to the increase of income per capita, if one assumes as constant the active/inactive labor force relation). It affirms the existence of three types of technological progress: capital-using or mechanization, which involves a falling output-capital ratio or a falling productivity capital; capital-saving technology, which involves an increasing output-capital ratio or an increasing productivity of capital; and a neutral technical progress, which results of the first and the second type neutralizing each other. I show how - in the process of economic growth - the 
profit rate, the wage rate, and the functional distribution of income between profits and wages vary in relation to these three types of technical progress.

Marx's theory on the falling tendency of the rate of profit hypothesis is only valid if and while the capital-using technological progress was dominant. If technological progress is assumed to be neutral, the profit rate will remain constant, while the wage rate will increase according to the growth of labor productivity. In the moment that capital-saving technology becomes dominant the wage-rate could increase more than the productivity rate, while the profit rate would remain constant.

The assumption of a constant rate of profit is based on two other assumptions besides the fact that mechanization is dominant just in the early periods of capitalist development: that there is no alternative form of economic organization to capitalism, and that capital accumulation and growth depend on a satisfying profit rate. Thus, the profit rate plays a central role in the model. Whenever there is a tendency to the fall of the rate of profit (as it happened between the late 1960s and the 1980s), the economic and political system reacts to restore it.

From this model, and from basic factual knowledge on the history of modern capitalism, it is possible to derive the stylized facts of capitalist growth. Britain and, more generally, the countries that first completed the capitalist revolution are taken for reference. Economic growth turned out in four phases: the Industrial Revolution, from late eighteenth century to around 1815; the Marx's or Competitive Phase, from 1815 to around 1873; the Oligopolistic Phase, from 1890 to 1929; Fordism, from 1946 to 1973; and the Financier-Rentier Capitalism, from 1979 to 2008. Since the 2008 Global Financial Crisis, capitalism in rich countries is undergoing a moment of transition and indetermination. Since the 1870 s to 1970 s, capitalism political strength was founded in the increase of real wages with the increase of productivity. This, plus its capacity to impulse technical progress were its two main trumps. Yet, wages are almost stagnant in rich countries since the 1970s, while the very rich, the richer 1\%, are booming. Capitalism didn't fail in Marx's time, but is failing in ours.

\section{REFERENCES}

Aglietta, Michel (2016), “America's slow down”. New Left Review, 100: 119-128.

Allen, Robert C. (2001) "The great divergence in European wages and prices from the middle ages to the First World War”, Explorations in Economic History 38 (4): 411-447.

Bakir, Erdogan and Al Campbell (2010) "Neoliberalism, the rate of profit and the rate of accumulation”, Science and Society 74 (3): 323-342.

Boddy, Radford and James Crotty (1975) "Class conflict and macro-policy: the political business cycle”, Review of Radical Political Economics 7(1): 1-9.

Brenner, Robert (2002) The Boom and the Bubble: The USA in the World Economy. Second edition. London: Verso.

Bresser-Pereira, Luiz Carlos (1972) "A Emergência da Tecnoburocracia” [The emergence of technobureaucracy], in Bresser-Pereira (1972) Tecnoburocracia e Contestação. Petrópolis: Editora Vozes. 
Republished in A Sociedade Estatal e a Tecnoburocracia [State Society and Technobureaucracy]. São Paulo: Editora Brasiliense, 1981.

Bresser-Pereira, Luiz Carlos (1977 [1980]) «Notes d'introduction au mode de production technobureaucratique", L'Homme et Société no. 55-58, 1980: 61-89. Original publication in Portuguese, 1977.

Bresser-Pereira, Luiz Carlos (1986) Lucro, Acumulação e Crise [Profit, Accumulation and Crisis]. São Paulo: Editora Brasiliense. Available as a Kindle edition.Bresser-Pereira, Luiz Carlos (2009) "The two methods and the hard core of economics", Journal of Post Keynesian Economics, 31 (3) spring: 493-522.

Bresser-Pereira, Luiz Carlos (2014) "Inequality and the phases of capitalism”, Forum for Social Economics 43 (3) September: 199-222.

Bresser-Pereira, Luiz Carlos (2017) "The two forms of capitalism: developmentalism and economic liberalism”, Brazilian Journal of Political Economy 37 (4) October 2017.

Brown, E. H. Phelps e Sheila V. Hopkins (1981) A Perspective of Wages and Price, London: Methuen. Chesnais, François (1994) La Mondialisation du Capital, Paris: Syros.

Clark, Gregory (2007) "The long march of history: Farm wages, population, and economic growth, England 1209-1869", The Review of Economic History 60 (1): 97-135.

Coutinho, Luciano e Luiz Gonzaga Belluzzo (1998) “'Financeirização' da riqueza, inflação de ativos e decisões de gasto em economias abertas" [Wealth's 'financialization', inflation of assets, and expenditure decisions in open economies], Economia e Sociedade, no. 11, December 1998: 137-150.

Duménil, Gérard and Dominique Lévy (1993) The Economics of the Profit Rate: Competition, Crises and Historical Tendencies in Capitalism, London: Edward Elgar.

Duménil, Gérard and Dominique Lévy (1996) La Dynamique du Capital. Un Siècle d'Économie Américaine, Paris: PUF.

Duménil, Gérard and Dominique Lévy (2002) "The Profit Rate: Where and How Much Did it Fall? Did it Recover? (USA 1948-2000)". Review of Radical Political Economics 34(4): 437-462.

Freeman, Alan (2012) "The profit rate in the presence of financial markets: a necessary correction", Journal of Australian Political Economy 70: 167-192.

Galbraith, John Kenneth (1967 [1979]) The New Industrial State, New York: Mentor Books, 1979. Originally published in 1967; revised in 1972.

Glyn, Andrew, A. Hughes, A. Lipietz, and A. Singh (1988) The Rise and Fall of the Golden Age, Helsinki: WIDER Working Papers, no.43, April.

Goldenstein, Jonathan P. (1999) "The simple analytics and empirics of the cyclical profit squeeze and cyclical underconsumption theories: clearing the air". Review of Radical Political Economics 31(2): 74-88.

Gordon, Robert J. (2016) The Rise and Fall of American Growth, Princeton: Princeton University Press.

Guttmann, Robert (2008) “A primer on finance-led capitalism and its crisis”, Revue de la Régulation $\mathrm{n}$. 3/4, second semester 2008: digital edition, no page numbers.

Guttmann, Robert (2016) Finance-Led Capitalism: Shadow banking, Re-Regulation, ad the Future of Global Markets, New York: Palgrave MacMillan.

Kaldor, Nicholas (1956) “A Model of Economic Growth”, Economic Journal 68: 591-624.

Marglin, Stephen A. (1990) "Lessons of the Golden Age: An Overview". In Marglin and Schor, eds. (1990): 1-38.

Marglin, Stephen A. and Juliet B. Schor, eds. (1990) The Golden Age of Capitalism. Oxford: Clarendon Press.

Marx, Karl (1867) Capital, Volume I. London: Penguin Books, 1979. Written between 1861 and 1866. Originally published in 1867.

Mills, C. Wright (1951) White Collar, The American Middle Class, New York: Oxford University Press. Okishio, Nobuo (1961) “Technical Changes and the Rate of Profit", Kobe University Economic Review, n.7.

Okishio, Nobuo (1977) "Notes on Technical Progress and Capitalist Society”, Cambridge Journal of Economics 1(1): 93-100. 
Piketty, Thomas (2013) Le Capital au XXI ${ }^{e m e}$ Siècle, Paris: Seuil.

Roberts, Michael (2009) The Great Recession: Profit Cycles, Economic Crisis, a Marxist View, No publisher name, ISBN 9781445244082.

Rostow, Walt W. (1960) The Stages of Economic Growth, Cambridge: Cambridge University Press.

Shaikh, Anwar (1978) "An introduction to the history of crisis theory". In Bruce Steinberg et al. (1978) U.S. Capitalism in Crisis, New York: The Union for Radical Political Economics.

Shaikh, Anwar (1992) "The falling rate of profit as the cause of long waves: theory and empirical evidence", in Alfred Kleinknecht, Ernest Mandel and Immanuel Wallerstein, eds. New Findings in Long-Wave Research, Berlin: Springer Verlag: 174-2002.

Simon, Herbert A. (1956[1979]) "Rational Choice and the Structure of Environment", in Herbert A. Simon (1979).

Simon, Herbert A. (1957) Models of Man, New York: Wiley.

Simon, Herbert A. (1979) Models of Thought, New Haven: Yale University Press.

Sraffa, Piero (1960) Production of Commodities by Means of Commodities, Cambridge: Cambridge University Press.

Strassmann, Paul A. (2004) "Facts and fantasies about productivity". Available at http://www.strassmann.com/pubs/fnf/factnfantasy.shtml.

Streeck, Wolfgang (2014), “How will capitalism end?”, New Left Review, 87: 35-66.

Summers, Lawrence (2014), "US economic prospect: secular stagnation, hysteresis, and the zero lower bound”, Business Economics, 49 (2): 65-73.

Wolff, Edward N. (2001) "The Recent Rise of Profits in the United States", Review of Radical Political Economics 33(3): 315-324. 